\title{
Interaction between $\alpha$-Melanocyte-Stimulating Hormone and Corticotropin-Releasing Hormone in the Regulation of Feeding and Hypothalamo-Pituitary-Adrenal Responses
}

\author{
Xin-Yun Lu, ${ }^{1}$ Gregory S. Barsh, ${ }^{2}$ Huda Akil, ${ }^{1}$ and Stanley J. Watson ${ }^{1}$ \\ ${ }^{1}$ University of Michigan School of Medicine, Mental Health Research Institute, Ann Arbor, Michigan 48109, and 2Departments of Pediatrics and Genetics, \\ Howard Hughes Medical Institute, Stanford University, Stanford, California 94305
}

\begin{abstract}
Both central $\alpha$-melanocyte-stimulating hormone and corticotropin-releasing hormone (CRH) have been implicated in feeding and neuroendocrine mechanisms. The anatomical overlap and functional similarities between these two neurotransmitter systems led to the hypothesis that CRH might act as one of the mediators of the central actions of the melanocortin system. By double-labeling in situ hybridization, a subpopulation of CRH neurons in the paraventricular nucleus of the hypothalamus (PVN) were shown to contain the melanocortin-4 receptor (MC4R), concentrated in the ventromedial part of the parvicellular PVN (up to 33\%). Intracerebroventricular injection of melanocortin agonist MTII to conscious and freely moving rats induced a rapid induction of CRH gene transcription in the PVN. This effect was accompanied by a rise in plasma corticosterone levels in a dose- and time-dependent manner, with the maximum response observed $30 \mathrm{~min}$ after MTII injection. MTII $(0.5 \mathrm{nmol})$-induced increase in plasma corticosterone was attenuated by the selective MC4R antagonist HS014 $(0.25-1.0 \mathrm{nmol})$ and nonselective $\mathrm{CRH}$ receptor antagonist $\alpha$-helical-CRH $\mathrm{C}_{-41}(0.125-0.5 \mathrm{nmol})$ in a dose-dependent manner. Moreover, the anorectic effect of MTII was evaluated at 1, 2, and $24 \mathrm{hr}$ after intracerebroventricular injection. Approximately half of the inhibitory effect of MTII $(0.5 \mathrm{nmol})$ on food intake was reversed by pretreatment with $\alpha$-helical-CRH${ }_{9-41}$ at 0.25 and $0.5 \mathrm{nmol}$ doses. Collectively, these results provide evidence that $\mathrm{CRH}$ acts as a downstream mediator of melanocortin signaling and contributes to the mechanisms by which the central melanocortin system controls feeding and neuroendocrine responses.
\end{abstract}

Key words: melanocortin-4 receptors; MTII; corticotropin-releasing hormone; $\alpha$-helical-CRH ${ }_{9-41}$; paraventricular nucleus of the hypothalamus; food intake; hypothalamo-pituitary-adrenal axis

\section{Introduction}

The central melanocortin system is defined by the agonist $\alpha$-melanocyte-stimulating hormone ( $\alpha$-MSH), the antagonist Agouti-related protein (AGRP), and three melanocortin receptors (MCRs) that are expressed in the CNS: MC3R, MC4R, and MC5R. $\alpha$-MSH is derived from the post-translational processing of the precursor protein proopiomelanocortin (POMC), which is primarily synthesized in the arcuate nucleus of the hypothalamus (Watson et al., 1978; Krieger, 1979; Gee et al., 1983), whereas AGRP is expressed exclusively in a subset of arcuate neurons, distinct from the cell population expressing POMC (Ollmann et al., 1997; Wilson et al., 1999).

The central melanocortin system has become the focus of much attention in recent years because of its critical role in the control of eating and related behaviors. For example, intracerebroventricular infusions of the agonists $\alpha$-MSH and MTII (a

\footnotetext{
Received Feb. 20, 2003; revised June 25, 2003; accepted June 30, 2003.

This study was supported by a pilot feasibility grant from the University of Michigan Gastrointestinal Peptide Research Center, National Institutes of Health Grant P30-DK-34933 (X.Y.L.), and National Institute of Mental Health Grant MH-42251 (S.J.W.). We are grateful to Audrey Seasholtz and John Stead for helpful comments, and to Jim Stewart for his assistance in collecting blood samples.

Correspondence should be addressed to Xin-Yun Lu, Department of Pharmacology, University of Texas Health Science Center at San Antonio, San Antonio, TX 78229. E-mail: xylu@umich.edu.

Copyright $\odot 2003$ Society for Neuroscience $\quad$ 0270-6474/03/237863-10\$15.00/0
}

synthetic melanocortin agonist of MC3R and MC4R) suppress food intake in several rodent models, as well as in nonhuman primates (Poggioli et al., 1986; Fan et al., 1997; Rossi et al., 1998; Thiele et al., 1998; Murphy et al., 2000; Koegler et al., 2001; Wirth et al., 2001). These anorectic effects of $\alpha$-MSH and MTII can be blocked by coadministration of the physiological antagonist AGRP (Rossi et al., 1998). Moreover, central administration of AGRP alone potently stimulates food intake (Hagan et al., 2000; Kim et al., 2000; Lu et al., 2001; Wirth and Giraudo, 2001). Consistent with these pharmacological findings, genetic manipulations resulting in overexpression of AGRP or deficiency of POMC synthesis lead to hyperphagia and obesity (Ollmann et al., 1997; Krude et al., 1998; Yaswen et al., 1999). There is evidence that the $\alpha$-MSH anorexigenic and AGRP orexigenic effects are integrated by MC4R. A targeted disruption of the MC4R gene in mice eliminates the anorectic effects of MTII (Marsh et al., 1999). In addition to the feeding effect, several pharmacological studies have suggested a role for the central melanocortin system in the regulation of the activity of the hypothalamo-pituitary-adrenal (HPA) axis (Calogero et al., 1988; Ludwig et al., 1998; Von Frijtag et al., 1998; Dhillo et al., 2002).

Although the neural mechanisms by which melanocortins control feeding and regulate the HPA axis remain mostly unknown, evidence suggests that CRH may be one of the candidates 
relaying melanocortin signaling. First, like $\alpha-\mathrm{MSH}$, central administration of corticotropin-releasing hormone $(\mathrm{CRH})$ and $\mathrm{CRH}$-related peptides induces anorectic effects (Rivest et al., 1989; Heinrichs and Richard, 1999; Richard et al., 2002). Second, it is well established that $\mathrm{CRH}$ neurons in the paraventricular nucleus of the hypothalamus (PVN) play a pivotal role in the regulation of the HPA axis (Vale et al., 1981). In addition to the functional similarities, the melanocortin and CRH systems exhibit anatomical overlap. For instance, MC4R mRNA is expressed in the medial parvicellular subdivision of the PVN, in which $\mathrm{CRH}$ neurons are predominantly located (Bloom et al., 1982; Hwang and Guntz, 1997). Also, studies have revealed that $\mathrm{CRH}$ neurons in the PVN are innervated by $\alpha-\mathrm{MSH}$ neuronal terminals (Liposits et al., 1988; Mihaly et al., 2002). On the basis of such a pattern of anatomical connections and the functional similarities between melanocortin and CRH systems, the present study hypothesizes that CRH may be involved in the mechanisms by which the central melanocortin system regulates feeding behavior and HPA axis. Thus, the first experiment examines the extent of colocalization of MC4R and CRH, whereas the second set of experiments examines the effects of activation of MC4R on $\mathrm{CRH}$ gene transcription. Finally, we explore the role of the endogenous CRH system in mediating the anorectic and neuroendocrine responses elicited by exogenous melanocortin agonist.

\section{Materials and Methods \\ Animals}

Adult male Sprague Dawley rats (Charles River Laboratories, Wilmington, MA) weighing 250-300 gm were housed in plastic cages. Animals had ad libitum access to water and food (Rodent Chow 5008; Ralston Purina, St. Louis, MO) and were maintained on a $12 \mathrm{hr}$ light schedule (on 6:00 A.M. to 6:00 P.M.), with constant temperature and humidity. Animals were allowed to acclimate to these housing conditions for 1 week before experiments began. All procedures described were approved by the University of Michigan Committee on Use and Care of Animals.

\section{Surgery}

After 1 week of habituation to the housing conditions, rats were anesthetized with sodium pentobarbital $(50 \mathrm{mg} / 100 \mathrm{gm}$ body weight, i.p.) for stereotaxic surgery. Animals were mounted on the stereotaxic instrument. To achieve the flat skull position, the incisor bar was adjusted until the heights of lambda and bregma were equal. Stainless-steel guide cannulas (26 gauge; Plastics One, Roanoke, VA) were implanted into the lateral ventricles, $+1.5 \mathrm{~mm}$ lateral and $-0.8 \mathrm{~mm}$ posterior to bregma, and $3.5 \mathrm{~mm}$ ventral to the surface of the skull. Guide cannulas were fixed to the skull with three screws and dental cement. A dummy cannula was placed into the guide cannula, protruding $1 \mathrm{~mm}$ below the tip of the guide cannula, to prevent blockage. After intracerebroventricular cannulation, rats were housed in individual cages. Animals were handled daily and habituated to the injection procedure for a minimum of $10 \mathrm{~d}$ to minimize stress. Placement of cannulas in the lateral ventricle was functionally confirmed by injection of $1 \mu \mathrm{l}$ of angiotensin II $(10 \mu \mathrm{M})$ on the fifth or sixth day after surgery. Only rats that drank $>5 \mathrm{ml}$ of tap water within $10 \mathrm{~min}$ after injection were used for the microinjection experiments.

\section{Microinjection}

Melanocortin agonist MTII (Phoenix Pharmaceuticals, Belmont, CA), MC4 receptor selective antagonist HS 014 (Phoenix Pharmaceuticals), and $\mathrm{CRH}$ receptor antagonist $\alpha$-helical- $\mathrm{CRH}_{9-41}$ (Peninsula Laboratories, San Diego, CA) were freshly dissolved in $0.9 \%$ sterile saline before use. All intracerebroventricular injections were performed on conscious, unstrained, freely moving rats in their home cages. Injections were made over 1 min using a 33 gauge stainless injector connected to a $10 \mu \mathrm{l}$ glass syringe, which was operated by an infusion pump set to dispense $2 \mu \mathrm{l}$ of solution per minute. The injector was inserted and extended $1 \mathrm{~mm}$ beyond the tip of the guide cannula. Drug solutions or vehicle were infused in a volume of $2 \mu \mathrm{l}$ delivered over $1 \mathrm{~min}$. An additional minute was allowed for diffusion and prevention of backflow through the needle track before the injector was withdrawn.

\section{Experimental protocol}

Experiment 1: Expression of MC4R mRNA in CRH-containing neurons in the $P V N$. Three animals that were naive to any experimental procedure were used to determine the degree of colocalization of MC4R mRNA and CRH mRNA in the PVN. Animals were killed by decapitation in the early light cycle. Brains were rapidly removed and frozen in isopentane-dry ice bath at $-40^{\circ} \mathrm{C}$ and stored at $-80^{\circ} \mathrm{C}$. Sections $(10 \mu \mathrm{m})$ were cut on a cryostat through the hypothalamus. Tissue sections were stored at $-80^{\circ} \mathrm{C}$ until processing for dual in situ hybridization.

Experiment 2: Effects of melanocortin agonist MTII on CRH gene transcription. Four groups of rats ( $n=5-6$ per group) were used. Two groups received intracerebroventricular saline injection, and the other two groups were injected with $1 \mathrm{nmol}$ of MTII. Intracerebroventricular injections were performed in the early light cycle (8:00-10:30 A.M.). Animals were killed by decapitation at 15 or 30 min after injection. Brains were removed, frozen, sectioned, and stored as described above until processing for intronic in situ hybridization.

Experiment 3: Effects of melanocortin agonist MTII on circulating corticosterone levels. For the time course of corticosterone in response to central administration of MTII, 44 rats were used. Forty animals received intracerebroventricular injection of saline $(n=20)$ or $1 \mathrm{nmol}$ of MTII $(n=20)$. Injections were made in the early light cycle (8:30-11:00 A.M.). This time was chosen because in the morning, basal activity of the hypothalamo-pituitary-adrenal axis is low, and the HPA is also highly responsive to both activating and inhibitory stimuli (Dallman et al., 1994). Saline-treated and MTII-treated animals were then randomly assigned to four groups and killed 2.5, 15, 30, and 120 min after injection. An additional group of animals $(n=4)$ was killed at time 0 without injection and served as baseline controls. Trunk blood was collected into heparin-treated tubes. Plasma was separated by centrifugation (3000 rpm for $15 \mathrm{~min}$ ) and frozen until corticosterone radioimmunoassays were conducted.

The dose-effect on circulating corticosterone was determined by injecting 0, 0.1, 0.5, or $1.0 \mathrm{nmol}$ doses of MTII between 8:30 and 11:00 A.M. On the basis of the time course data, a blood sample was taken by tailnick $30 \mathrm{~min}$ after intracerebroventricular injection. Animals were mildly restrained while tail-nick was conducted. A tail vein was cut with a razor blade, and blood was collected in a heparinized capillary tube for the determination of plasma corticosterone levels.

Experiment 4: Effects of a CRH receptor antagonist and a selective melanocortin MC4R antagonist on MTII-induced plasma corticosterone response. In our initial experiments, we used $1 \mathrm{nmol}$ of MTII to induce an increase in circulating corticosterone levels. This high-dose effect, however, could not be attenuated with several doses of the nonselective CRH antagonist $\alpha$-helical- $\mathrm{CRH}_{9-41}$. Considering the potential ceiling effect of MTII and the agonistic property of $\alpha$-helical- $\mathrm{CRH}_{9-41}$ for CRH receptors at high doses (Menzaghi et al., 1994), we therefore lowered the dosage of MTII to $0.5 \mathrm{nmol}$ instead of trying to further elevate the dosage of $\alpha$-helical- $\mathrm{CRH}_{9-41}$ for the subsequent experiments. To examine the role of CRH in the MTII-induced changes in plasma corticosterone levels, six groups of animals ( $n=4-16$ per group) were pretreated with $\alpha$-helical-CRH ${ }_{9-41}$ at $0,0.125,0.25$, and $0.5 \mathrm{nmol} 10 \mathrm{~min}$ before injection of $0.5 \mathrm{nmol}$ of MTII or saline. Blood samples were taken by tail-nick at $30 \mathrm{~min}$ after MTII injection. Furthermore, to determine whether the actions of MTII on the activity of the HPA axis were mediated by the MC4R, four additional groups of animals ( $n=4-6$ per group) were infused with the selective MC4R antagonist HS014 at 0.25, 0.5, or 1.0 nmol 10 min before injection of 0.5 of nmol MTII or saline. Blood samples were taken by tail-nick at $30 \mathrm{~min}$ after MTII injection. Experiments for HS014 and $\alpha$-helical-CRH ${ }_{9-41}$ shared saline-saline and saline-MTII treatment groups.

Experiment 5: Effects of a CRH receptor antagonist on MTII-induced suppression of food intake. For the feeding study, spontaneous food intake and body weight were measured for each rat $2 \mathrm{~d}$ before injection. These two parameters were counterbalanced across different treatment groups. 
Food was removed $1 \mathrm{hr}$ before the dark cycle. Intracerebroventricular injections were performed at 15-20 min before the dark cycle (between 5:40 and 6:00 P.M.). To examine whether $\alpha$-helical- $\mathrm{CRH}_{9-41}$ could attenuate the MTII-induced anorectic effects, we first replicated the doseresponse relationship between MTII and food intake. Subsequently, a moderate effective dose of MTII $(0.5 \mathrm{nmol})$ was used to induce anorectic effects. $\alpha$-helical- $\mathrm{CRH}_{9-41}$ at $0,0.25$, and $0.5 \mathrm{nmol}$ doses was infused to block CRH receptors 10 min before injection of $0.5 \mathrm{nmol}$ of MTII or saline (five groups; $n=8-16$ per group). After injection, a preweighed chow hopper was placed in the home cages at the onset of the dark cycle (6:00 P.M.). Food intake was measured by weighing the remaining pellets and the spillage at 1,2, and $24 \mathrm{hr}$ after injection. A red light was provided during the measurement of food consumption in the dark cycle. To minimize disruption of food accessibility, preweighed food was provided in two sets of containers for each animal.

Single-labeling in situ hybridization for CRH heteronuclear RNA Antisense ${ }^{35} \mathrm{~S}$-labeled cRNA probes for rat $\mathrm{CRH}$ heteronuclear RNA (hnRNA) (530 mer, complementary to the intron sequence) were generated with ${ }^{35} \mathrm{~S}$-UTP and ${ }^{35} \mathrm{~S}$-CTP using the standard transcription system. Brain sections were fixed in $4 \%$ paraformaldehyde for $1 \mathrm{hr}$ and rinsed in $2 \times \mathrm{SSC}(300 \mathrm{~mm} \mathrm{NaCl}, 30 \mathrm{~mm} \mathrm{Na}$ citrate, $\mathrm{pH} 7.2)$. Sections were acetylated in $0.1 \mathrm{~m}$ triethanolamine, $\mathrm{pH} 8.0$, with $0.25 \%$ acetic anhydride (for $10 \mathrm{~min})$ and dehydrated through a graded series of alcohol (50-100\%). ${ }^{35}$ S-labeled cRNA probes were diluted to $3 \times 10^{4} \mathrm{cpm} / \mu \mathrm{l}$ in $50 \%$ hybridization buffer $(50 \%$ formamide, $10 \%$ dextran sulfate, $3 \times$ SSC, $50 \mathrm{~mm}$ sodium phosphate buffer, $\mathrm{pH} 7.4,1 \times$ Denhardt's solution, $0.1 \mathrm{mg} / \mathrm{ml}$ yeast tRNA, and $10 \mathrm{~mm} \mathrm{DTT).} \mathrm{Brain} \mathrm{sections} \mathrm{were} \mathrm{hybridized} \mathrm{with} 70 \mu \mathrm{l}$ of the diluted probes at $55^{\circ} \mathrm{C}$ overnight. Sections were rinsed in $2 \times \mathrm{SSC}$ and incubated in RNase A buffer containing $200 \mu \mathrm{g} / \mathrm{ml}$ RNase A for $1 \mathrm{hr}$ at $37^{\circ} \mathrm{C}$ followed by a series of washes of increasing stringency $(2 \times, 1 \times$, $0.5 \times$, and $0.1 \times$ SSC, for $5 \mathrm{~min}$ each at room temperature). Finally, the sections were placed in $0.1 \times$ SSC at $65^{\circ} \mathrm{C}$ for $1 \mathrm{hr}$, rinsed in distilled water, and dehydrated in a graded series of alcohol. Brain sections were exposed to $\mathrm{x}$-ray film for $14 \mathrm{~d}$.

Levels of CRH hnRNA were evaluated by analyzing film autoradiography. Films were visualized under a CCD camera (Model XC-77; Sony, Tokyo, Japan), and brain section images were captured and analyzed with the AIS image analysis system (Imaging Research, Ontario, Canada). Signals were expressed as optical density levels above threshold. The threshold level was defined as 3.5 SDs above the mean optical density of a fiber tract region. Results were expressed as integrated optical density, which is the product of the signal intensity and number of pixels above the threshold within the defined brain region. Equivalent planes of coronal brain sections through the PVN were ensured for analysis between animals.

\section{Double-labeling in situ hybridization for colocalization of MC4R} $m R N A$ and $C R H$ mRNA

cRNA probes complementary to either the rat MC4R mRNA (1040 mer; courtesy of Ira Gantz, University of Michigan, Ann Arbor, MI) or the rat $\mathrm{CRH}$ mRNA were labeled with ${ }^{35} \mathrm{~S}$-UTP and ${ }^{35} \mathrm{~S}$-CTP (for the MC4R probe) or digoxigenin (dig)-UTP (for the CRH probe) using standard transcription methods. Brain sections were hybridized with a mixture of ${ }^{35} \mathrm{~S}$-MC4R and dig-CRH probes at $55^{\circ} \mathrm{C}$ overnight. Sections were rinsed in $2 \times$ SSC, treated with RNase A $(200 \mu \mathrm{g} / \mathrm{ml})$ for $1 \mathrm{hr}$ at $37^{\circ} \mathrm{C}$, and washed in $2 \times, 1 \times, 0.5 \times$, and $0.1 \times$ SSC (for 5 min each). Sections were placed in $0.1 \times \mathrm{SSC}$ at $65^{\circ} \mathrm{C}$ for $1 \mathrm{hr}$ followed by immunohistochemical staining for visualization of digoxigenin-labeled CRH probe. Brain sections were treated with a blocking solution $(0.1 \mathrm{M}$ phosphate buffer containing $0.5 \%$ Triton X-100 and $0.25 \%$ carageenan, $\mathrm{pH} 7.5$ ) for $4 \mathrm{hr}$, and then incubated overnight with an antibody against digoxigenin and conjugated to alkaline phosphatase (sheep anti-dig-AP, and Fab fragments, Boehringer Mannheim, Indianapolis, IN), diluted 1:15,000. After rinsing twice in both $0.1 \mathrm{M}$ phosphate buffer and $0.1 \mathrm{M}$ Tris buffer (30 min each), sections were incubated with color reaction buffer containing $0.45 \%$ nitroblue tetrazolium chloride (Boehringer Mannheim), $0.35 \%$ 5-bromo-4-chloro-3-indoylphosphate 4-toluidine salt (Boehringer Mannheim), 5\% polyvinyl alcohol, and $0.24 \%$ levamizole. Color reac- tion was completed in $3 \mathrm{hr}$. Sections were rinsed in water and incubated with $0.1 \mathrm{M}$ glycine buffer, $\mathrm{pH} 2.2$, containing $0.5 \%$ Triton X-100 for 10 min. Finally, sections were fixed in $2.5 \%$ glutaraldehyde for $2 \mathrm{hr}$. After rinsing in water and dehydrating in a graded series of alcohol, sections were dipped in liquid emulsion (Ilford KD-5; Polysciences, Warrington, $\mathrm{PA})$, air-dried, and stored in a dark box at $4^{\circ} \mathrm{C}$. After $14 \mathrm{~d}$ of exposure to emulsion, sections were developed, fixed, dehydrated, and coverslipped in a xylene-based mounting medium (Permount; Fisher Scientific, Houston, TX). CRH mRNA labeled with nonradioactive dig-probe was visualized as a purple-blue precipitate, and MC4R mRNA labeled with radioactive probe was visualized as silver grains. For evaluation of the colocalization of MC4R mRNA and CRH mRNA, six consecutive sections through the PVN were analyzed. Signal specificity was ensured either by hybridization with sense-strand probes or pretreatment of brain sections with RNase A $\left(200 \mu \mathrm{g} / \mathrm{ml}\right.$ at $37^{\circ} \mathrm{C}$ for $\left.60 \mathrm{~min}\right)$.

\section{Plasma corticosterone analysis}

Plasma corticosterone was assayed using a highly specific corticosterone antibody developed in our laboratory. Briefly, $10 \mu \mathrm{l}$ duplicate samples of plasma were heated at $70^{\circ} \mathrm{C}$ for $30 \mathrm{~min}$ to denature corticosterone-binding protein and incubated overnight with corticosterone antibody and $\left[{ }^{3} \mathrm{H}\right]$ corticosterone (Amersham, Arlington Heights, IL). Free and bound corticosterone were separated by incubation with charcoal for $15 \mathrm{~min}$.

\section{Statistical analysis}

All results were analyzed by a one-way or two-way ANOVA followed by Bonferroni-Dunn post hoc testing. Significance levels were taken as $p<$ 0.05 .

\section{Results}

\section{Colocalization of MC4R and CRH in the PVN}

The PVN consists of a number of distinct subdivisions, including five parvicellular and three magnocellular subdivisions (Swanson and Kuypers, 1980; Swanson et al., 1986). MC4R mRNA exhibited heterogeneity of distribution in the PVN with strong signals in the dorsal and medial parvicellular subdivisions. MC4R mRNA was also detectable in the anterior, ventral, and lateral parvicellular and magnocellular subdivisions of the PVN (Fig. 1). As reported previously (Swanson et al., 1986), CRH neurons are present predominantly in the medial parvicellular subdivision. $\mathrm{CRH}$ cells were also observed in the anterior parvicellular and anterior magnocellular subdivisions. Dual in situ hybridization histochemistry showed that a subset of CRH cells labeled for the MC4R were distributed in the anterior, ventromedial, and dorsal parvicellular subdivisions of the PVN (Figs. 2, 3). Overall, 10$15 \%$ of $\mathrm{CRH}$-containing neurons in the PVN expressed the MC4R mRNA. However, up to $33 \%$ of the CRH neurons in the ventromedial part of the parvicellular PVN contained the MC4R. In contrast, the dorsolateral part of the parvicellular PVN had a low level of MC4R mRNA.

\section{Melanocortin signaling and $\mathrm{CRH}$ gene expression}

To determine whether activation of the MC4R stimulated CRH gene transcription, we used a CRH hnRNA probe to detect its intronic sequence. Introns are removed rapidly posttranscriptionally before translation, so they will report on levels of de novo gene transcription. Levels of CRH hnRNA in the PVN were determined after infusion of melanocortin agonist MTII or vehicle into the lateral ventricle of conscious rats. We found that $\mathrm{CRH}$ hnRNA levels increased rapidly and dramatically after intracerebroventricular infusion of $1 \mathrm{nmol}$ MTII, whereas animals injected with vehicle exhibited low expression of CRH hnRNA (Fig. 4A,B). An eightfold induction in CRH hnRNA was observed 15 min after injection of MTII (58.5 \pm 15.8 vs $460 \pm 187.6$; vehicle vs MTII; $p<0.01)$. This induction appeared to be short- 
lived because CRH hnRNA levels declined 30 min after injection $(56 \pm 26.9$ vs $297 \pm$ 139.0; vehicle vs MTII; $p<0.05)$.

Functional interaction between melanocortin and CRH systems Evidence from our colocalization and expression data described above (Results) suggests a functional link between $\mathrm{CRH}$ and melanocortin systems. We therefore decided to investigate consequences of melanocortin-induced activation of CRH expression with respect to two physiological functions, namely the hypothalamopituitary-adrenal axis activity and food intake.

\section{Melanocortin signaling and corticosterone secretion}

It is well established that stimulation of CRH expression in the PVN and peptide release in the median eminence lead to HPA axis activation (Rivest et al., 1989; Heinrichs and Richard, 1999; Richard et al., 2002). Thus, one physiological consequence of PVN CRH activation would be its stimulatory actions on the pituitaryadrenal axis. First, we examined the time course of the effects of MTII on circulating corticosterone. The plasma corticosterone level was analyzed at $2.5,15,30$, and 120 min after intracerebroventricular injection of $1 \mathrm{nmol}$ MTII. ANOVA conducted for plasma corticosterone concentrations revealed a significant interaction between treatment and time $\left(F_{(1,38)}=8.9 ; p<\right.$ $0.01)$. As shown in Figure $5 A$, plasma cor-

ticosterone levels increased rapidly from baseline values of $1.45 \pm$ $0.80 \mu \mathrm{g} / \mathrm{dl}$ to a maximum of $25.9 \pm 3.65 \mu \mathrm{g} / \mathrm{dl} 30 \mathrm{~min}$ after injection of $1 \mathrm{nmol}$ MTII and returned to the baseline level by 120 $\min (3.9 \pm 2.19 \mu \mathrm{g} / \mathrm{dl})$. MTII treatment significantly increased plasma corticosterone levels relative to vehicle treatment at 15 and $30 \mathrm{~min}$ after injection. A smaller increase in plasma corticosterone levels was observed at $15 \mathrm{~min}$ after vehicle injection but subsided rapidly at $30 \mathrm{~min}$, reflecting a small and short-lived $(<30 \mathrm{~min})$ stress response to intracerebroventricular injection in conscious animals.

The dose-response for MTII is shown in Figure 5B. One-way ANOVA revealed that MTII dose-dependently increased circulating corticosterone concentrations at $30 \mathrm{~min}$ after injection compared with the vehicle condition $\left(F_{(3,17)}=12.12 ; p<\right.$ $0.0005)$. MTII at 0.5 and $1.0 \mathrm{nmol}$ doses significantly increased plasma corticosterone levels. The magnitude of the increase induced by $1 \mathrm{nmol}$ MTII was comparable with the time course study with the same dose at the $30 \mathrm{~min}$ time point. On the basis of our preliminary observations, we chose to use a $0.5 \mathrm{nmol}$ dose of MTII for additional experiments. Figure $6 \mathrm{~A}$ shows the effect of pretreatment with the selective MC4 receptor antagonist HS014 on the MTII-induced rise in circulating corticosterone levels. ANOVA revealed a significant effect of treatment $\left(F_{(5,36)}=11.462 ; p<0.0001\right)$. Post hoc analyses indicated that HSO 14 at $0.25,0.5$, and $1.0 \mathrm{nmol}$ significantly antagonized the MTII ( $0.5 \mathrm{nmol})$-induced increase in plasma corticosterone levels $(0.25 \mathrm{nmol}, p<0.01 ; 0.5 \mathrm{nmol}, p<0.05 ; 1.0 \mathrm{nmol}, p<$
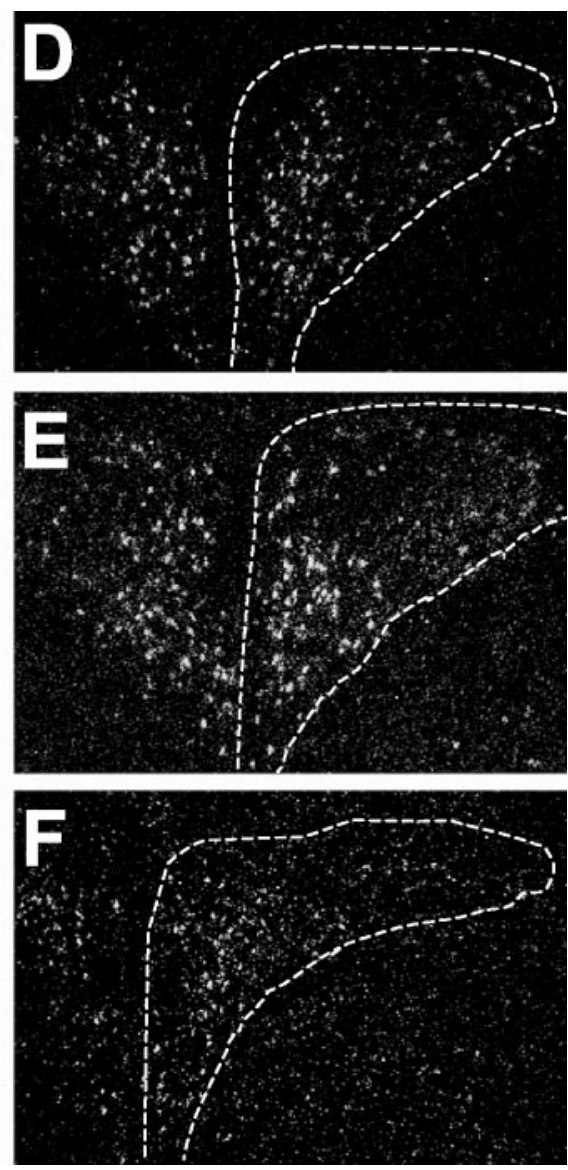

Figure 1. Dark-field emulsion autoradiograms showing the distribution of MC4R mRNA in the PVN of the rat hypothalamus. In The sections are $100 \mu \mathrm{m}$ apart. Locations of the PVN are indicated with dashed lines. MC4R mRNA-expressing cells are distributed in the anterior, dorsal, ventral, medial, and posterior parvicellular subdivisions of the PVN. Scattered MC4R-containing neurons were also noted in the magnocellular subdivision of the PVN.

0.0001). HS014 alone had no effect compared with the vehicle-vehicle condition $(p=0.269)$. Figure $6 B$ shows the effect of pretreatment with different doses of $\alpha$-helical- $\mathrm{CRH}_{9-41}$ on the MTIIelicited increase in circulating corticosterone levels. ANOVA revealed a significant effect of treatment $\left(F_{(5,37)}=9.146 ; p<\right.$ $0.0001)$. Post hoc analyses indicated that pretreatment with the doses of 0.25 and $0.5 \mathrm{nmol}$ of $\alpha$-helical- $\mathrm{CRH}_{9-41}$ significantly attenuated the effect of MTII on plasma corticosterone levels $(0.25 \mathrm{nmol}, p<$ 0.05 ; $0.5 \mathrm{nmol}, p<0.001)$. $\alpha$-helical- $\mathrm{CRH}_{9-41}$ alone produced no significant effect on circulating corticosterone levels, compared with the vehicle-vehicle condition $(p=0.649)$.

\section{Melanocortin signaling and feeding}

Because both the $\mathrm{CRH}$ and melanocortin systems regulate feeding behavior, we examined whether the endogenous CRH system was involved in the feeding effects induced by melanocortin signaling. As shown in Figure 7, injections of MTII at 0.1 and 1.0 nmol doses resulted in significant decreases in food intake over 2, 4, and $24 \mathrm{hr}$ periods, compared with the vehicle condition. A moderate dose of MTII ( $0.5 \mathrm{nmol})$ was used to induce anorexia, and the role of CRH in MTII-induced anorexia was further characterized (Fig. 8$)$. We found that MTII $(0.5 \mathrm{nmol})$ significantly decreased spontaneous food intake over 1, 2, and $24 \mathrm{hr}$ periods. Although the $\mathrm{CRH}$ receptor antagonist $\alpha$-helical- $\mathrm{CRH}_{9-41}$ alone had no effect on food intake, it significantly attenuated the sup- 

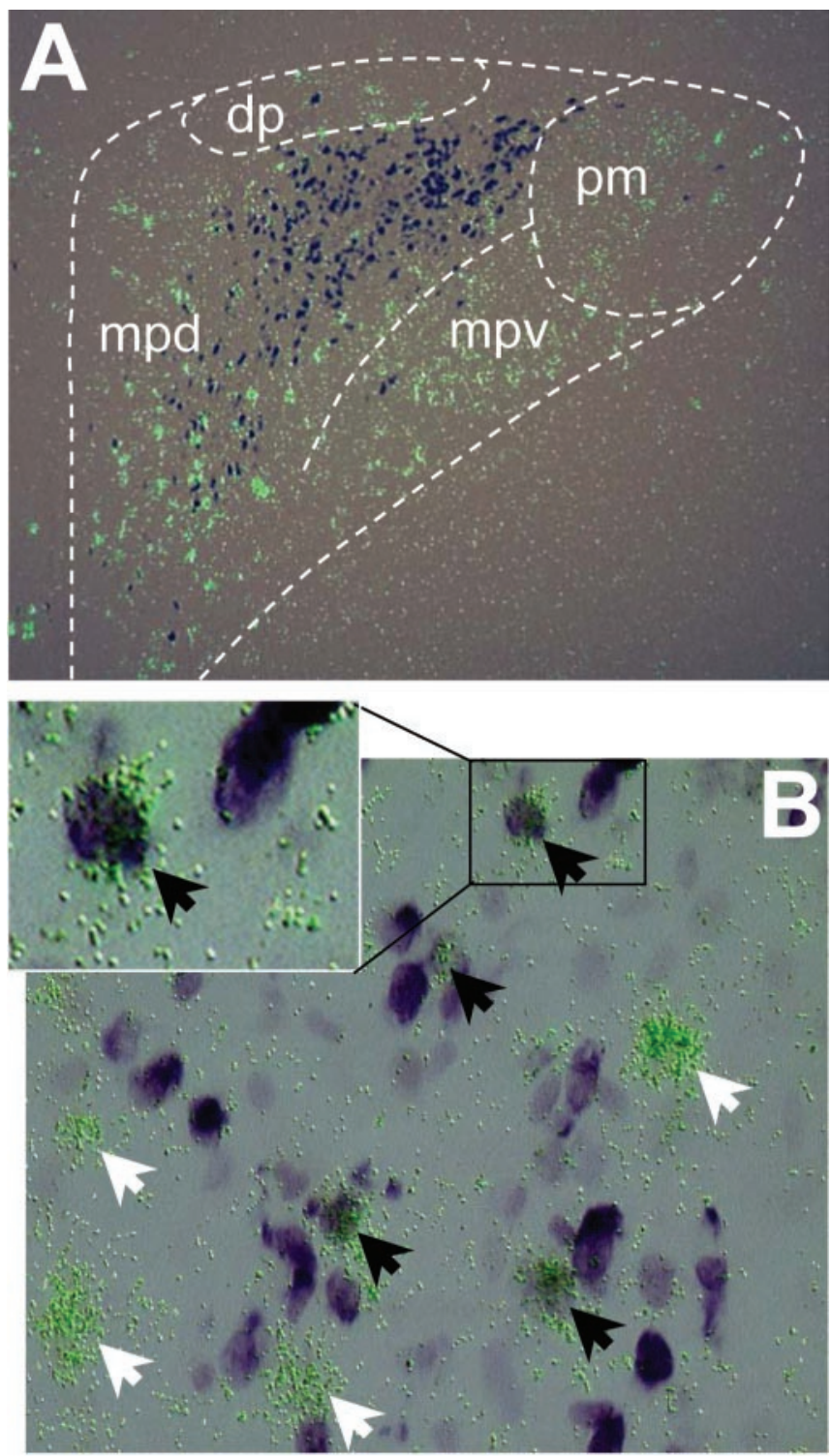

Figure 2. Colocalization of MC4R mRNA and CRH in the PVN. A, Microscopic images of dual in situ hybridization histochemistry of MC4R mRNA $\left({ }^{35}\right.$ S-labeled riboprobe, clusters of green grains) and CRH mRNA (digoxigenin-labeled riboprobe, dark purple cells). Subdivisions of the PVN: dp, dorsal parvicellular; mpd, medial parvicellular, dorsal aspect; mpv, medial parvicellular, ventral aspect; pm, posterior magnocellular. $B$, High magnification of microscopic images showing double-labeled cells. Black arrows indicate cells double-labeled for MC4R mRNA and CRH mRNA. White arrows indicate cells labeled for MC4R mRNA only.

pressive effect of MTII on food intake. Repeated measures of ANOVA for the drug, time, and interaction effects were as follows: $F_{(3,41)}=20.4, p<0.0001 ; F_{(3,41)}=552.7, p<0.001$; $F_{(3,41)}=12.0, p<0.001 . \alpha$-helical-CRH ${ }_{9-41}$ at 0.25 and $0.5 \mathrm{nmol}$ doses significantly attenuated MTII-induced suppression of food intake at 1,2, and $24 \mathrm{hr}$ (Fig. 8) after injection compared with the vehicle-vehicle group. However, neither dose completely abolished the anorectic effects of MTII at any time points. Food intake over $24 \mathrm{hr}$ in the groups treated with $\alpha$-helical- $\mathrm{CRH}_{9-41}(0.25$ and $0.5 \mathrm{nmol})$ and MTII $(0.5 \mathrm{nmol})$ was significantly lower than vehicle-treated controls ( $75 \%$ of the vehicle-vehicle condition; $p<0.01$ ). Approximately half of the anorectic effect of MTII was reversed by the $\mathrm{CRH}$ receptor antagonist.
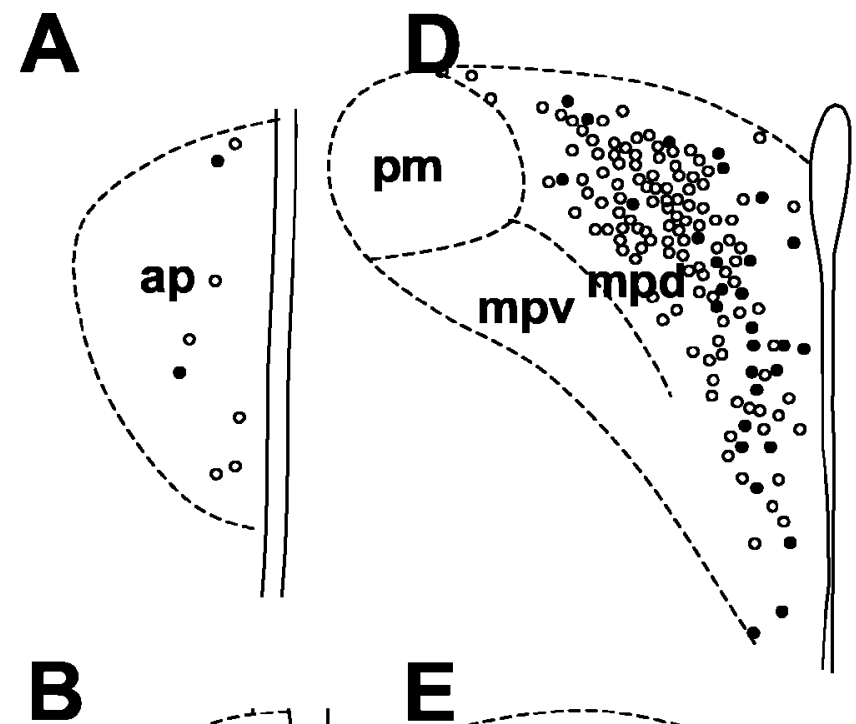

B
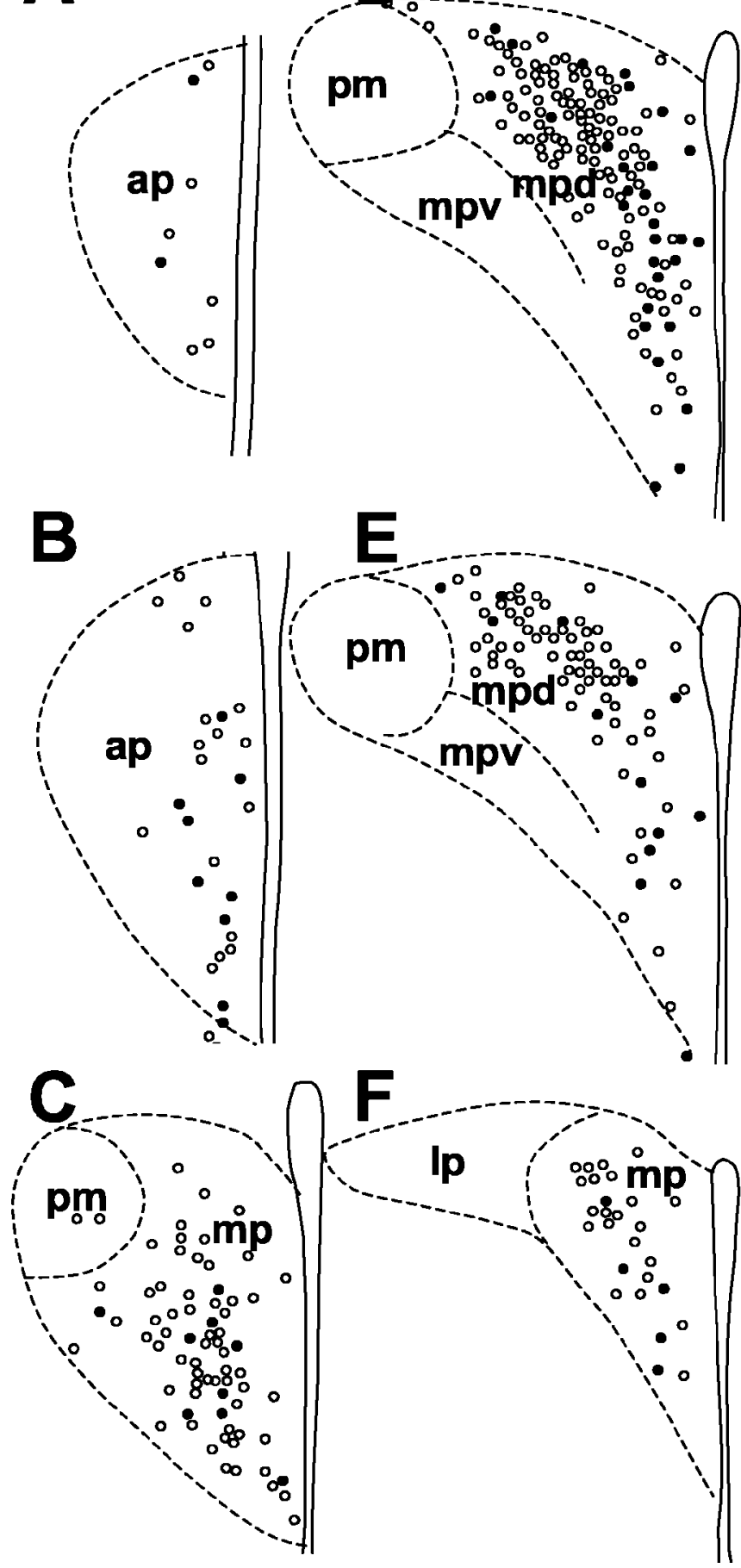

Figure 3. Schematic drawing indicating the distribution of CRH neurons that express MC4R mRNA in the paraventricular nucleus of the hypothalamus ( $A-F$ in a rostrocaudal sequence). Open circles indicate cells single labeled for CRH mRNA, and closed circles represent cells double labeled for both MC4R and CRH mRNA. ap, Anterior parvicellular; Ip, lateral parvicellular; mp, medial parvicellular; mpd, medial parvicellular, dorsal aspect; mpv, medial parvicellular, ventral aspect; pm, posterior magnocellular.

\section{Discussion}

We have described a range of evidence for a functional link between the central melanocortin and CRH systems. First, we showed that a subpopulation of CRH neurons contained MC4R in the PVN. Second, central administration of the melanocortin agonist MTII was observed to stimulate $\mathrm{CRH}$ gene transcription. 


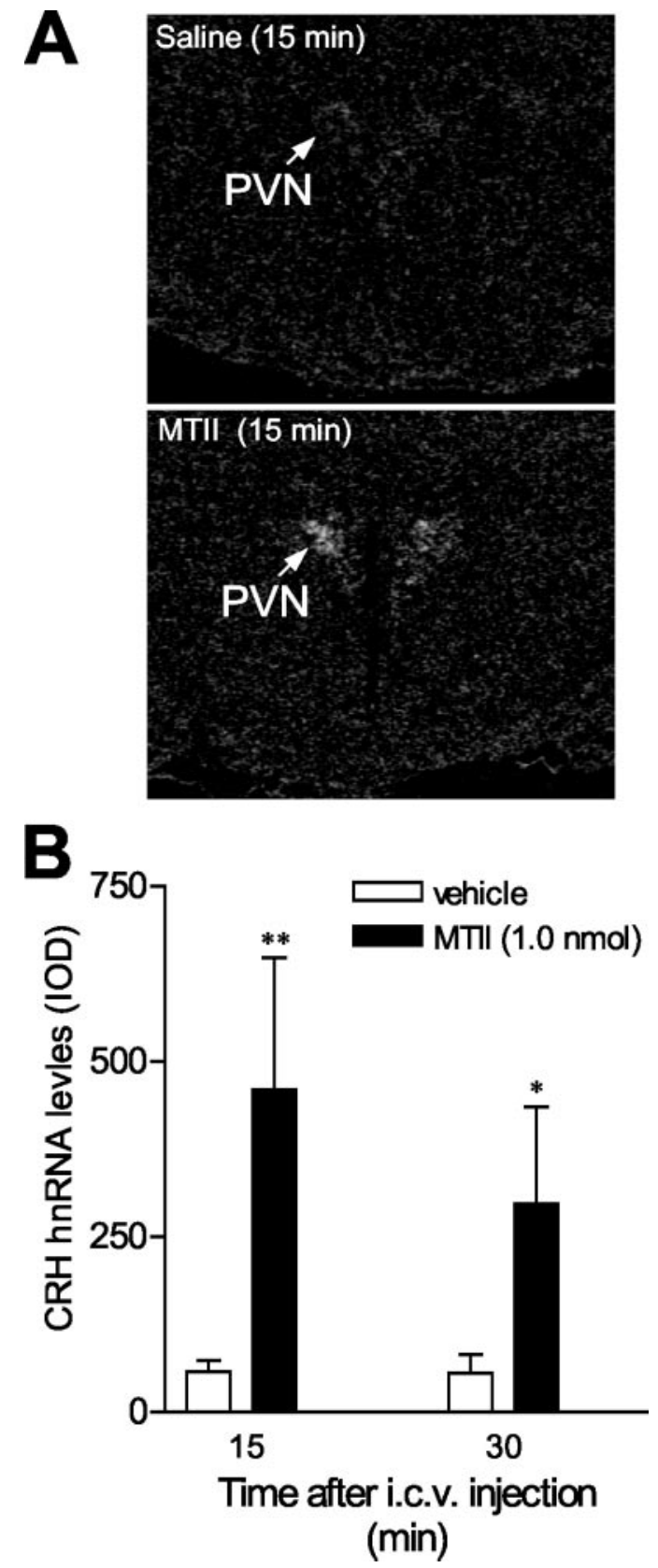

Figure 4. Changes in CRH heteronuclear RNA levels in the PVN after intracerebroventricular (i.c.v.) infusion of melanocortin agonist MTII $(1 \mathrm{nmol})$ or vehicle into the lateral ventricle of conscious, freely moving rats. CRH hnRNA levels were detected using an intronic in situ hybridization. $A$, Dark-field film autoradiographs showing induction of CRH hnRNA by melanocortin agonist MTII (bottom) compared with the vehicle treatment (top). B, Induction of CRH hnRNA after intracerebroventricular injection of $1 \mathrm{nmol}$ of MTII ( $n=5-6$ per group). ${ }^{*} p<0.05$, ${ }^{* *} p<0.01$ versus vehicle-treated controls. IOD, Integrated optical density.

Third, we confirmed and extended previous reports of the anorectic and neuroendocrine effects elicited by melanocortin agonists. We demonstrated that MTII activated the HPA axis, which appeared to be mediated by the MC4R, and it inhibited food intake in a time-related and dose-dependent manner. These effects were significantly attenuated by pretreatment with $\mathrm{CRH}$ antagonist $\alpha$-helical- $\mathrm{CRH}_{9-41}$, indicating that $\mathrm{CRH}$ lies functionally downstream of melanocortin signaling and may represent one of the neurochemical pathways through which the melanocortin system regulates its feeding and neuroendocrine functions.
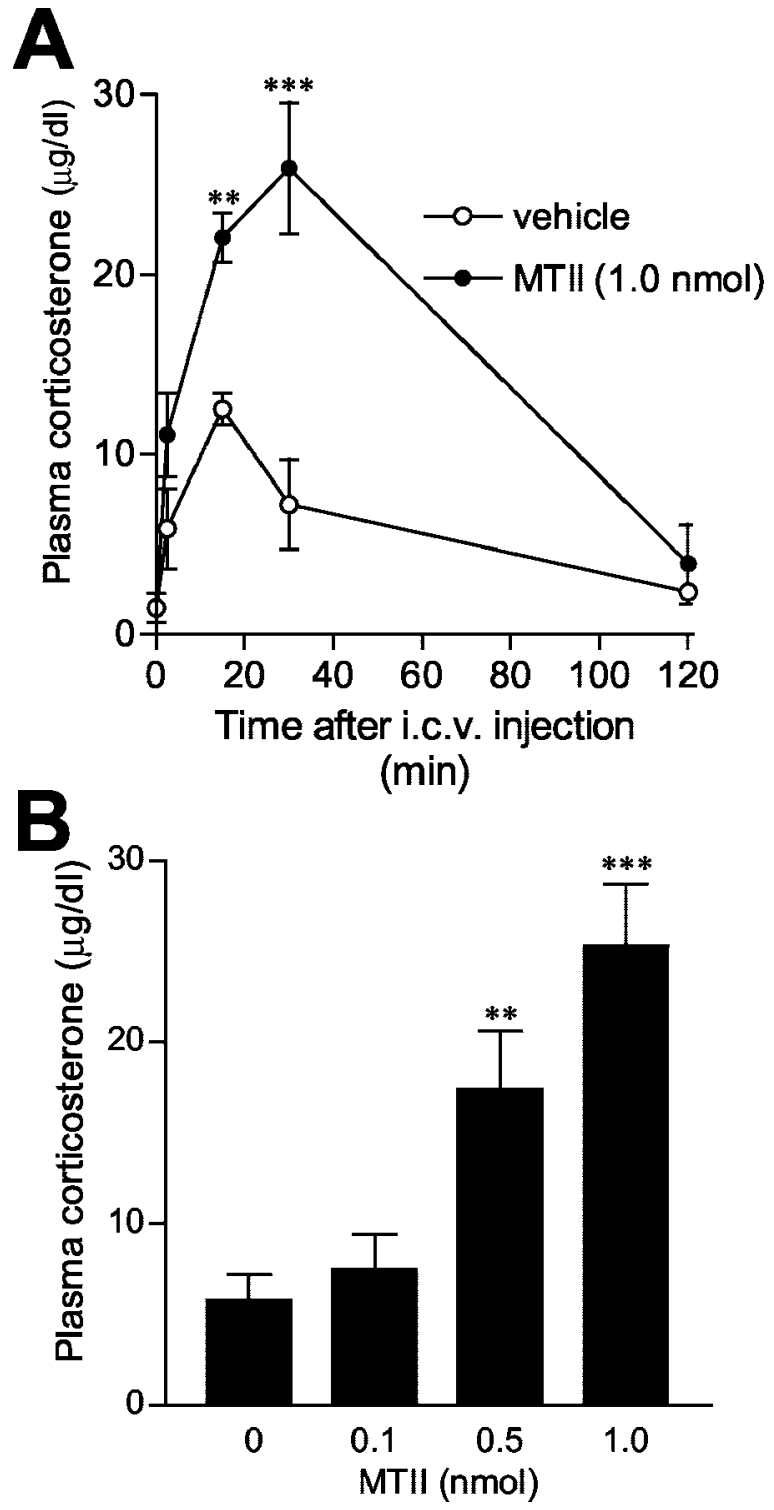

Figure 5. A, Time course of plasma corticosterone levels in response to intracerebroventricular (i.c.v.) injection of MTII (1 nmol) or vehicle to conscious, freely moving rats. Corticosterone levels increased rapidly after infusion of MTII and reached the peak at 30 min after injection. A smaller, short-lived increase in corticosterone levels was also observed after vehicle injection. Data are expressed as the mean \pm SEM ( $n=5-6$ per group). B, Dose-effect of MTII. MTII dose-dependently increased plasma corticosterone levels. Data are expressed as mean $\pm \mathrm{SEM}$ ( $n=6$ for vehicle; $n=4$ for $0.1 \mathrm{nmol}$ of MTIl; $n=5$ for $0.5 \mathrm{nmol}$ of MTIl; $n=6$ for $1.0 \mathrm{nmol}$ of MTII). ${ }^{* *} p<0.01,{ }^{* * *} p<0.001$ versus vehicle-treated controls.

Interaction between melanocortin and CRH systems

Using double-labeling in situ hybridization, we have demonstrated for the first time that MC4R is expressed in a subset of $\mathrm{CRH}$ neurons in the PVN. These neurons are concentrated in the ventromedial part of the parvicellular PVN, in accordance with the prominent projections of $\alpha$-MSH in this subdivision (Liposits et al., 1988; Bagnol et al., 1999; Mihaly et al., 2002). This coexistence of MC4R and CRH provides an anatomical basis for the possible direct interaction between endogenous $\alpha$-MSH and PVN CRH neurons. Consistent with this interaction, we have found that genetic inactivation of MC4R in mice results in a dramatic decrease in CRH mRNA levels in the PVN (our unpublished data). However, previous pharmacological studies on the effect of $\alpha$-MSH on CRH mRNA in the PVN have been contra- 


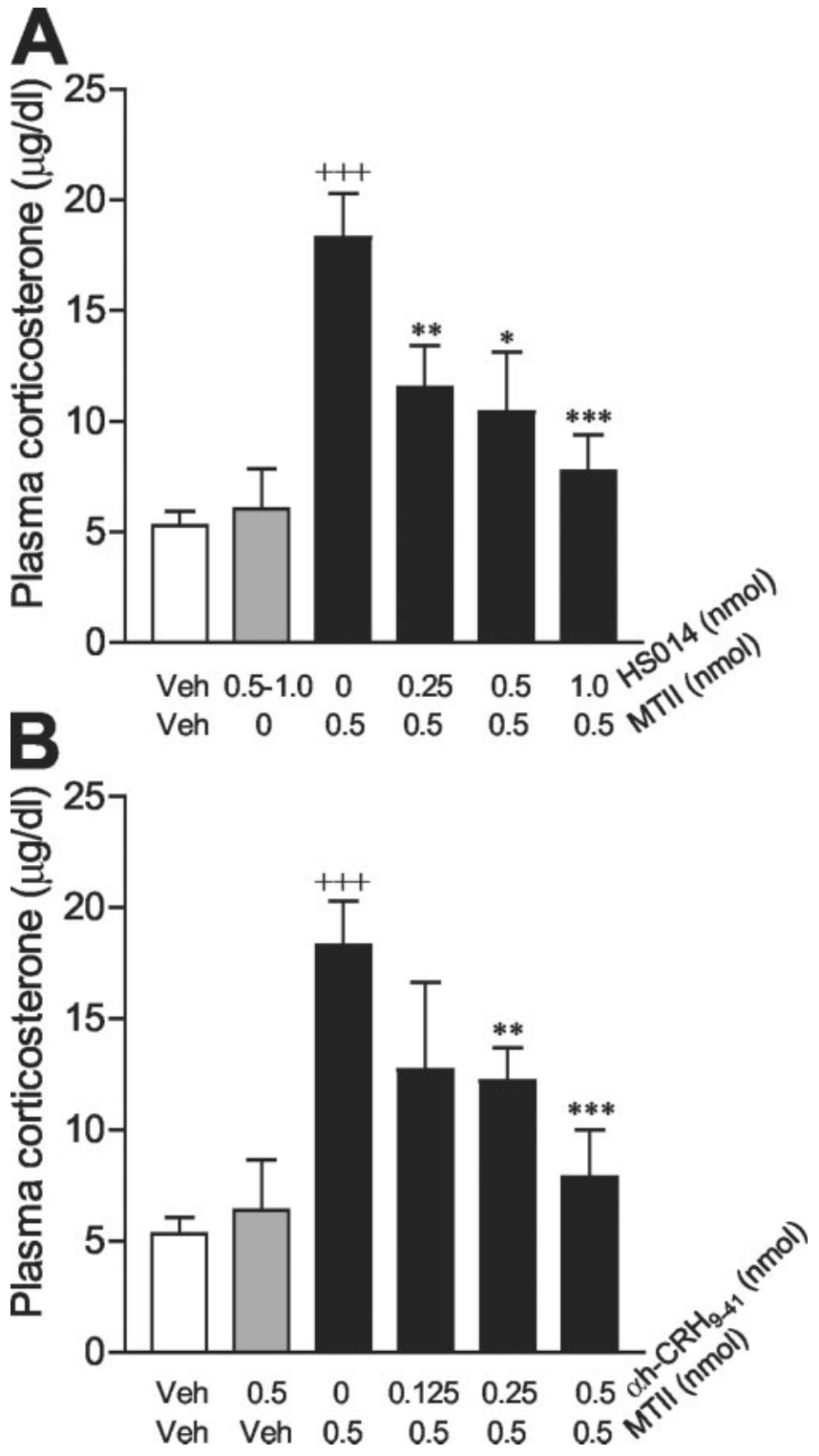

Figure 6. Effects of blockade of MC4Rs and CRH receptors on MTII-elicited effects on circulating corticosterone levels. A, Blockade of MC4Rs with the selective MC4R antagonist HSO14. The treatment groups were as follows: vehicle (Veh) plus vehicle $(n=16), 0.5-1.0 \mathrm{nmol}$ of HS014 plus vehicle $(n=6)$, vehicle plus $0.5 \mathrm{nmol}$ of MTII $(n=8), 0.25 \mathrm{nmol}$ of HS014 plus 0.5 $\mathrm{nmol}$ of MTII $(n=4), 0.5 \mathrm{nmol}$ of HSO14 plus $0.5 \mathrm{nmol}$ of MTII $(n=4), 1.0 \mathrm{nmol}$ of HSO14 plus $0.5 \mathrm{nmol}$ of MTII $(n=6)$. B, Blockade of CRH receptors with the nonselective CRH receptor antagonist $\alpha$-helical-- $\mathrm{CRH}_{9-41}\left(\alpha \mathrm{h}\right.$-CRH $\left.{ }_{9-41}\right)$. The treatment groups were as follows: vehicle plus vehicle $(n=16) ; 0.5 \mathrm{nmol}$ of $\alpha$-helical- $\mathrm{CRH}_{9-41}$ plus vehicle $(n=6)$; vehicle plus $0.5 \mathrm{nmol}$ of MTII $(n=8) ; 0.125 \mathrm{nmol}$ of $\alpha$-helical-CRH ${ }_{9-41}$ plus $0.5 \mathrm{nmol}$ of MTII $(n=4) ; 0.25 \mathrm{nmol}$ of $\alpha$-helical- $\mathrm{CRH}_{9-41}$ plus $0.5 \mathrm{nmol}$ of MTII ( $n=7$ ); and $0.5 \mathrm{nmol}$ of $\alpha$-helical- $\mathrm{CRH}_{9-41}$ plus 0.5 $\mathrm{nmol}$ of MTII $(n=4)$. Data are expressed as mean \pm SEM. ${ }^{+++} p<0.0001$ versus vehiclevehicle; ${ }^{*} p<0.05 ;{ }^{* *} p<0.01 ;{ }^{* * *} p<0.001$ versus vehicle -0.5 nmol of MTII.

dictory. For example, one study found that CRH mRNA levels were unaffected by continuous infusion of $\alpha$-MSH for $6 \mathrm{~d}$ to rats with ad libitum access to food, whereas another reports that CRH mRNA expression was increased by intermittent treatment with $\alpha$-MSH (every $6 \mathrm{hr}$ for $64 \mathrm{hr}$ ) in fasted animals (Fekete et al., 2000; McMinn et al., 2000). Discrepancies between these studies may be attributable to the sizable pool of CRH mRNA, the dosage of $\alpha$-MSH, and different chronic treatment regimens used in these studies.

In the present study, we used a heteronuclear RNA probe,

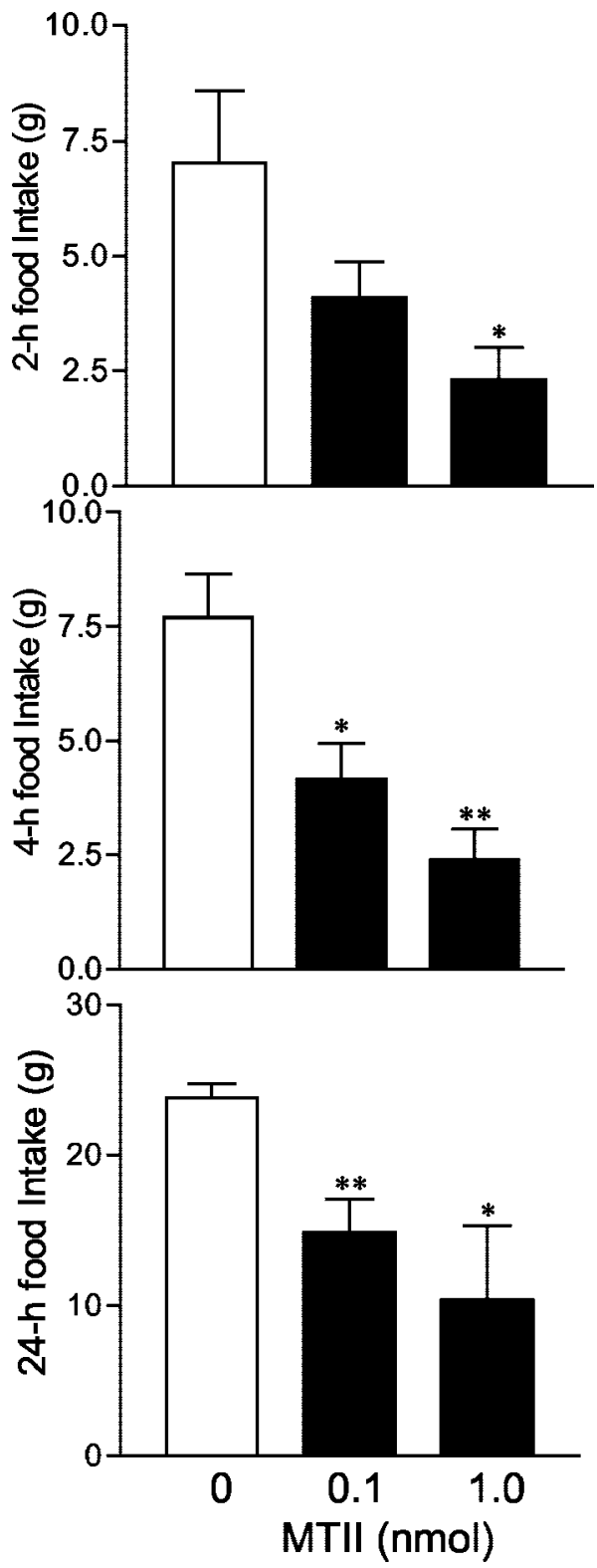

Figure 7. Effect of MTIl on spontaneous food intake. Central administration of MTIl suppresses food intake ( $n=5$ per group). ${ }^{*} p<0.05 ;{ }^{* *} p<0.01$ versus the vehicle-treated group.

which detected the intron sequence of $\mathrm{CRH}$ hnRNA, thus providing a reliable indicator of changes in de novo $\mathrm{CRH}$ gene transcription. CRH hnRNA levels increased dramatically $15 \mathrm{~min}$ after central administration of MTII and declined with increasing time. Considering that a subpopulation of CRH neurons contains MC4R, MTII may activate CRH gene transcription directly through the MC4R on these neurons. However, in contrast to the subdivision-specific colocalization pattern of MC4R and $\mathrm{CRH}$, MTII-induced activation of $\mathrm{CRH}$ gene transcription in the PVN displayed a generalized effect without notable subdivisional preference. Consistent with our findings, Sarkar and colleagues (2002) recently reported that phosphorylated cAMP response element-binding protein, a neuronal activation marker, was induced in $>50 \%$ of PVN CRH neurons by central administration of $\alpha$-MSH. Thus, it is likely that the effects of melanocortin agonists on CRH neurons recruit additional mechanisms either via positive feedback within the PVN or through excitatory relaying nuclei. In fact, an ultrashort positive feedback of CRH on its own 

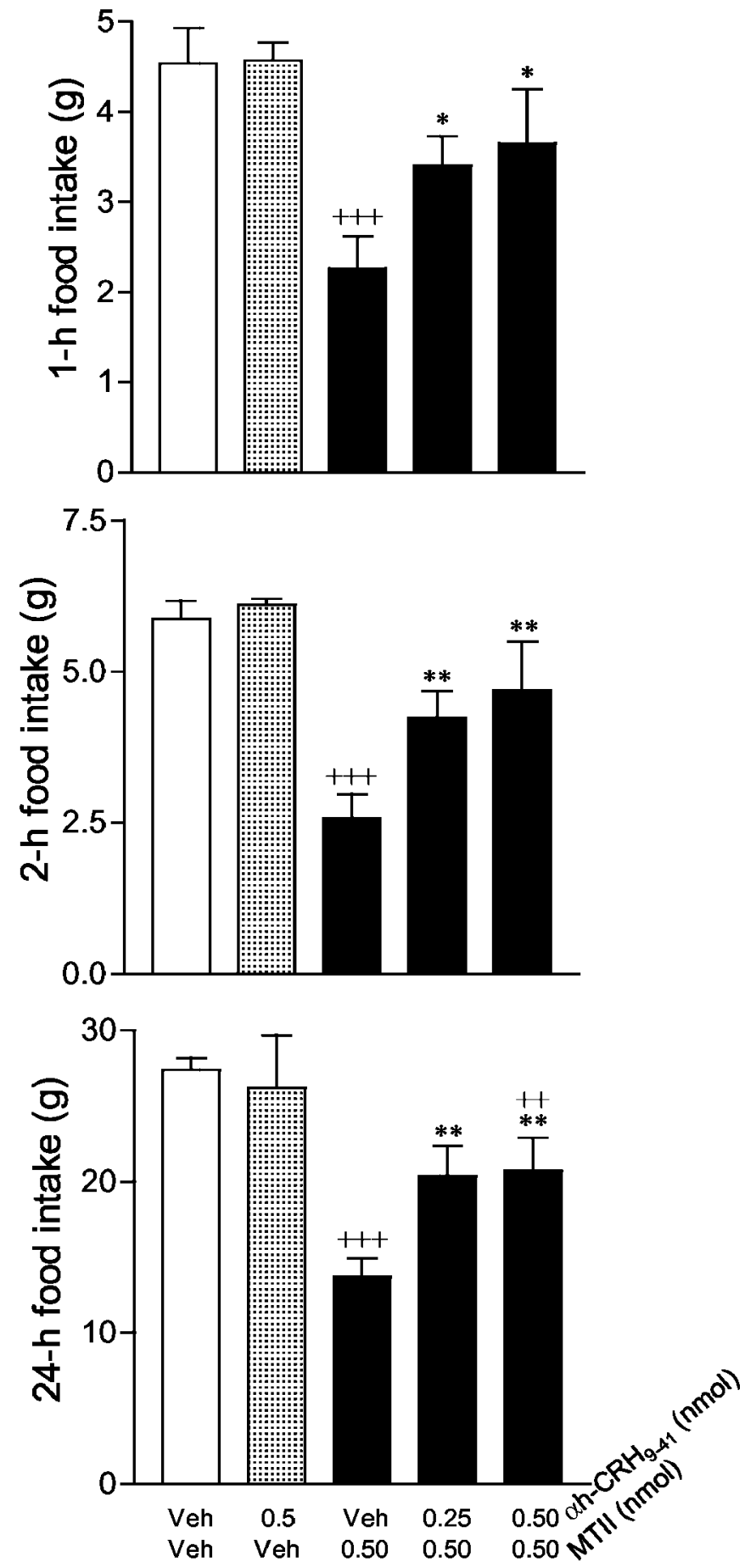

Figure 8. Effect of $\alpha$-helical-CRH ${ }_{9-41}\left(\alpha \mathrm{h}\right.$ - $\left.\mathrm{CRH}_{9-41}\right)$ on MTIl-induced suppression of food intake. The treatment groups were as follows: vehicle (Veh) plus vehicle $(n=12) ; 0.5 \mathrm{nmol}$ of $\alpha$-helical-CRH ${ }_{-41}$ plus vehicle $(n=3)$; vehicle plus $0.5 \mathrm{nmol}$ of MTII $(n=16) ; 0.25 \mathrm{nmol}$ of $\alpha$-helical-CRH ${ }_{9-41}$ plus $0.5 \mathrm{nmol}$ of MTII ( $n=8$ ); and $0.5 \mathrm{nmol}$ of $\alpha$-helical- $\mathrm{CRH}_{9-41}$ plus 0.5 nmol of MTII $(n=8)$. Data represent the mean \pm SEM, as measured by grams of food intake. ${ }^{+++} p<0.0001 ;{ }^{++} p<0.01$ for comparisons with vehicle-vehicle; ${ }^{* *} p<0.01 ;{ }^{*} p<$ 0.05 for comparisons with vehicle $-0.5 \mathrm{nmol}$ of MTII.

biosynthesis within the PVN has been proposed on the basis of observations of a CRH-induced increase in expression of $\mathrm{CRH}$ and CRH1 receptor in this region (Imaki et al., 1996; Mansi et al., 1996). Therefore, increased CRH biosynthesis and resultant release induced by MC4R activation might subsequently induce positive autoregulation and generalize its effect through the
CRH1 receptor in a paracrine manner (Makino et al., 2002). It is also possible that melanocortin agonists may regulate $\mathrm{PVN} C \mathrm{CRH}$ gene transcription through those extra-PVN structures that contain melanocortin receptors and send excitatory inputs to the PVN, such as the amygdala.

\section{Physiological correlates of melanocortin-CRH interaction} Central injections of the melanocortin agonist MTII to conscious, freely moving rats induced anorexia and increased the plasma concentrations of corticosterone in a time-related and dose-dependent manner. Although the MTII-induced anorexia has been thought to be mediated by the MC4R because of the inability of MTII to suppress food intake in MC4R - / - mice (Marsh et al., 1999), it was unknown which melanocortin receptor was involved in the melanocortin-induced neuroendocrine response. We have shown here that pretreatment with a selective MC4R antagonist, HS014, blocks MTII-elicited rise in plasma corticosterone levels, suggesting that MC4R mediates the MTIIinduced activation of the HPA axis.

$\mathrm{CRH}$ has been well characterized as a primary factor regulating basal and stress-induced activity of the HPA axis (Rivest et al., 1989; Heinrichs and Richard, 1999; Richard et al., 2002). The combination of increased CRH gene transcription in the PVN and elevated plasma corticosterone levels elicited by melanocortin agonist MTII suggests that the activation of the CRH system might serve as one of the mechanisms by which melanocortins stimulate the pituitary-adrenal axis. To test this hypothesis, we used a CRH antagonist, $\alpha$-helical- $\mathrm{CRH}_{9-41}$, to block CRH receptors before central administration of MTII. $\alpha$-helical-CRH $\mathrm{CH}_{9-41}$ significantly attenuated the rise in plasma corticosterone levels induced by a moderate dose of MTII $(0.5 \mathrm{nmol})$. However, in our initial experiment, $\alpha$-helical- $\mathrm{CRH}_{9-41}$ failed to attenuate the effect elicited by a high dose of MTII ( $1 \mathrm{nmol})$, although MTII at this dose was observed to increase $\mathrm{CRH}$ gene transcription. One of the possibilities is that $1 \mathrm{nmol}$ of MTII might induce the ceiling effect on circulating corticosterone levels, which made clear blockade impossible with the doses of $\alpha$-helical- $\mathrm{CRH}_{9-41}$ used in this study. Indeed, we found that the magnitude of circulating corticosterone levels induced by $1 \mathrm{nmol}$ of MTII was comparable with $30 \mathrm{~min}$ restraint stress $(25-30 \mu \mathrm{g} / \mathrm{dl})$. Another possibility is that MTII at high doses may directly influence the activity of the pituitary-adrenal axis. This notion is supported by our observations of $\alpha$-MSH-immunoreactive fibers in the median eminence (Bagnol et al., 1999) and identification of melanocortin receptors in the pituitary (Lorsignol et al., 1999).

$\mathrm{CRH}$ is not only a major regulator of neuroendocrine responses, but it produces anorectic effects when administered centrally (Richard et al., 2002). CRH receptor antagonist $\alpha$-helical$\mathrm{CRH}_{9-41}$ has been shown to reverse CRH- and stress-induced suppression of feeding (Krahn et al., 1986; Heinrichs and Koob, 1992; Heinrichs et al., 1992; Menzaghi et al., 1993). In the present study, we found that blockade of CRH receptors with $\alpha$-helical$\mathrm{CRH}_{9-41}$ significantly attenuated MTII-induced anorexia. Central infusions of this compound alone had no effect on food intake, suggesting that its blockade of MTII-induced anorexia was not attributable to its intrinsic properties. These results suggested that altering endogenous CRH activity may serve as one of the mechanisms by which melanocortin agonists and antagonists regulate appetite. Although the precise sites for the melanocortin-CRH interaction in the control of appetite are unclear, our anatomical and expression data, along with findings from other researchers, suggest a role for the PVN. For example, $\alpha$-MSH and MTII act as potent inhibitors of food intake when injected di- 
rectly into the PVN (Giraudo et al., 1998; Kim et al., 2000). In addition, food deprivation decreases $\mathrm{CRH}$ mRNA levels in the PVN (Suemaru et al., 1986; Brady et al., 1990), and lesions of CRH neurons in this region markedly enhance feeding (Menzaghi et al., 1993). However, we cannot exclude the involvement of neural substrates other than $\mathrm{CRH}$ in the mediation of melanocortin-induced anorexia, because the effects of MTII were only attenuated and not completely returned to the control level by $\mathrm{CRH}$ receptor antagonist $\alpha$-helical- $\mathrm{CRH}_{9-41}$. Using other $\mathrm{CRH}$ receptor antagonists that do not have agonistic effects might reveal an even higher contribution of CRH.

The biological actions of CRH are mediated via two receptor subtypes, CRH1 and CRH2. These two receptor subtypes exhibit distinct anatomical distribution and pharmacological specificity (Richard et al., 2002). Although the action of CRH on the HPA axis function has been proposed to be predominantly CRH1 mediated, it has been suggested that the feeding effects of $\mathrm{CRH}$ primarily involve CRH2 (Steckler and Holsboer, 1999). However, because the $\mathrm{CRH}$ antagonist used in the present study cannot distinguish these receptor subtypes, whether the feeding and neuroendocrine responses induced by melanocortin agonism are mediated by $\mathrm{CRH}$ through distinct $\mathrm{CRH}$ receptors will require further investigation.

Alteration of the CRH system and correlated feeding and neuroendocrine responses elicited by melanocortin agonist MTII, as indicated in the present study, raise a question. Is the feeding effect of MTII dependent on its effect on the HPA axis, or vice versa, or are they independent? The experiments here were not designed to address this question, because we chose different optimal times to investigate the responses of the HPA axis and food intake. We examined plasma corticosterone levels in response to central administration of MTII in the early light cycle, when basal activity of the HPA axis is low and the responsiveness of the HPA axis is maximal to a given stimulus, whereas the experiments for feeding were performed after the onset of the dark cycle, when animals normally eat. In view of the ability of $\alpha$-MSH to decrease food intake in mice with adrenal gland deficiency (Yaswen et al., 1999), we would propose that the melanocortin-induced anorectic effects may not be dependent on its actions on the pituitary-adrenal axis.

\section{Implications for eating and affective disorders}

Hyperactivity of the HPA axis and overproduction of CRH have been implicated in anorexia nervosa and affective disorders such as stress, depression, and anxiety (Licinio et al., 1996; Arborelius et al., 1999). Here, we have shown evidence that the melanocortin system may be a key regulator of the HPA axis and CRH production. Consistent with our findings, the site at which MC4R is most expressed on CRH neurons (the ventromedial part of the parvicellular PVN) has been reported recently to play a dominant role in sustaining HPA hyperactivity in the repeated stress condition (Viau and Sawchenko, 2002). In addition, a role for the melanocortin system in human eating disorders is supported by the recent identification of association between defects in the human AGRP gene and MC4R gene with anorexia nervosa and obesity, respectively (Barsh et al., 2000; Vink et al., 2001). Given the comorbidity between eating disorders and stress-related disorders (Kennedy et al., 1994), a better understanding of the central melanocortin system in the modulation of eating and stress responses will provide insight into the etiology of these disorders.

In conclusion, the present study delineates an anatomical and functional relationship between the central melanocortin and $\mathrm{CRH}$ systems. Our observations provide direct evidence that melanocortin agonism functions as a rapid enhancer of $\mathrm{CRH}$ synthesis and that melanocortin agonists may mediate their effects on both feeding and HPA functions via activation of the $\mathrm{CRH}$ system.

\section{References}

Arborelius L, Owens MJ, Plotsky PM, Nemeroff CB (1999) The role of corticotropin-releasing factor in depression and anxiety disorders. J Endocrinol 160:1-12.

Bagnol D, Lu XY, Kaelin CB, Day HE, Ollmann M, Gantz I, Akil H, Barsh GS, Watson SJ (1999) Anatomy of an endogenous antagonist: relationship between Agouti-related protein and proopiomelanocortin in brain. J Neurosci 19:RC26(1-7).

Barsh GS, Farooqi IS, O’Rahilly S (2000) Genetics of body-weight regulation. Nature 404:644-651.

Bloom FE, Battenberg EL, Rivier J, Vale W (1982) Corticotropin releasing factor (CRF): immunoreactive neurones and fibers in rat hypothalamus. Regul Pept 4:43-48.

Brady LS, Smith MA, Gold PW, Herkenham M (1990) Altered expression of hypothalamic neuropeptide mRNAs in food-restricted and fooddeprived rats. Neuroendocrinology 52:441-447.

Calogero AE, Gallucci WT, Gold PW, Chrousos GP (1988) Multiple feedback regulatory loops upon rat hypothalamic corticotropin-releasing hormone secretion. Potential clinical implications. J Clin Invest 82:767-774.

Dallman MF, Akana SF, Levin N, Walker CD, Bradbury MJ, Suemaru S, Scribner KS (1994) Corticosteroids and the control of function in the hypothalamo-pituitary-adrenal (HPA) axis. Ann NY Acad Sci 746:22-31.

Dhillo WS, Small CJ, Seal LJ, Kim MS, Stanley SA, Murphy KG, Ghatei MA, Bloom SR (2002) The hypothalamic melanocortin system stimulates the hypothalamo-pituitary-adrenal axis in vitro and in vivo in male rats. Neuroendocrinology 75:209-216.

Fan W, Boston BA, Kesterson RA, Hruby VJ, Cone RD (1997) Role of melanocortinergic neurons in feeding and the agouti obesity syndrome. Nature 385:165-168.

Fekete C, Legradi G, Mihaly E, Tatro JB, Rand WM, Lechan RM (2000) alpha-Melanocyte stimulating hormone prevents fasting-induced suppression of corticotropin-releasing hormone gene expression in the rat hypothalamic paraventricular nucleus. Neurosci Lett 289:152-156.

Gee CE, Chen CL, Roberts JL, Thompson R, Watson SJ (1983) Identification of proopiomelanocortin neurones in rat hypothalamus by in situ cDNA-mRNA hybridization. Nature 306:374-376.

Giraudo SQ, Billington CJ, Levine AS (1998) Feeding effects of hypothalamic injection of melanocortin 4 receptor ligands. Brain Res 809:302-306.

Hagan MM, Rushing PA, Pritchard LM, Schwartz MW, Strack AM, Van Der Ploeg LH, Woods SC, Seeley RJ (2000) Long-term orexigenic effects of AgRP-(83-132) involve mechanisms other than melanocortin receptor blockade. Am J Physiol Regul Integr Comp Physiol 279:R47-R52.

Heinrichs SC, Koob GF (1992) Corticotropin-releasing factor modulates dietary preference in nutritionally and physically stressed rats. Psychopharmacology 109:177-184.

Heinrichs SC, Richard D (1999) The role of corticotropin-releasing factor and urocortin in the modulation of ingestive behavior. Neuropeptides 33:350-359.

Heinrichs SC, Cole BJ, Pich EM, Menzaghi F, Koob GF, Hauger RL (1992) Endogenous corticotropin-releasing factor modulates feeding induced by neuropeptide $\mathrm{Y}$ or a tail-pinch stressor. Peptides 13:879-884.

Hwang BH, Guntz JM (1997) Downregulation of corticotropin-releasing factor mRNA, but not vasopressin mRNA, in the paraventricular hypothalamic nucleus of rats following nutritional stress. Brain Res Bull 43:509-514.

Imaki T, Naruse M, Harada S, Chikada N, Imaki J, Onodera H, Demura H, Vale W (1996) Corticotropin-releasing factor up-regulates its own receptor mRNA in the paraventricular nucleus of the hypothalamus. Brain Res Mol Brain Res 38:166-170.

Kennedy SH, Kaplan AS, Garfinkel PE, Rockert W, Toner B, Abbey SE (1994) Depression in anorexia nervosa and bulimia nervosa: discriminating depressive symptoms and episodes. J Psychosom Res 38:773-782.

Kim MS, Rossi M, Abusnana S, Sunter D, Morgan DG, Small CJ, Edwards CM, Heath MM, Stanley SA, Seal LJ, Bhatti JR, Smith DM, Ghatei MA, Bloom SR (2000) Hypothalamic localization of the feeding effect of 
agouti-related peptide and alpha-melanocyte-stimulating hormone. Diabetes 49:177-182.

Koegler FH, Grove KL, Schiffmacher A, Smith MS, Cameron JL (2001) Central melanocortin receptors mediate changes in food intake in the rhesus macaque. Endocrinology 142:2586-2592.

Krahn DD, Gosnell BA, Grace M, Levine AS (1986) CRF antagonist partially reverses CRF- and stress-induced effects on feeding. Brain Res Bull $17: 285-289$

Krieger DT (1979) Physiological significance of hypophysiotrophic and pituitary hormones on brain. Eur J Clin Invest 9:107-110.

Krude H, Biebermann H, Luck W, Horn R, Brabant G, Gruters A (1998) Severe early-onset obesity, adrenal insufficiency and red hair pigmentation caused by POMC mutations in humans. Nat Genet 19:155-157.

Licinio J, Wong ML, Gold PW (1996) The hypothalamic-pituitary-adrenal axis in anorexia nervosa. Psychiatry Res 62:75-83.

Liposits Z, Sievers L, Paull WK (1988) Neuropeptide-Y and ACTHimmunoreactive innervation of corticotropin releasing factor (CRF)synthesizing neurons in the hypothalamus of the rat. An immunocytochemical analysis at the light and electron microscopic levels. Histochemistry 88:227-234.

Lorsignol A, Vande Vijver V, Ramaekers D, Vankelecom H, Denef C (1999) Detection of melanocortin-3 receptor mRNA in immature rat pituitary: functional relation to gamma3-MSH-induced changes in intracellular $\mathrm{Ca}^{2+}$ concentration? J Neuroendocrinol 11:171-179.

Lu XY, Nicholson JR, Akil H, Watson SJ (2001) Time course of short-term and long-term orexigenic effects of Agouti-related protein (86-132). NeuroReport 12:1281-1284.

Ludwig DS, Mountjoy KG, Tatro JB, Gillette JA, Frederich RC, Flier JS, Maratos-Flier E (1998) Melanin-concentrating hormone: a functional melanocortin antagonist in the hypothalamus. Am J Physiol 274:E627-633.

Makino S, Hashimoto K, Gold PW (2002) Multiple feedback mechanisms activating corticotropin-releasing hormone system in the brain during stress. Pharmacol Biochem Behav 73:147-158.

Mansi JA, Rivest S, Drolet G (1996) Regulation of corticotropin-releasing factor type 1 (CRF1) receptor messenger ribonucleic acid in the paraventricular nucleus of rat hypothalamus by exogenous CRF. Endocrinology 137:4619-4629.

Marsh DJ, Hollopeter G, Huszar D, Laufer R, Yagaloff KA, Fisher SL, Burn P, Palmiter RD (1999) Response of melanocortin-4 receptor-deficient mice to anorectic and orexigenic peptides. Nat Genet 21:119-122.

McMinn JE, Wilkinson CW, Havel PJ, Woods SC, Schwartz MW (2000) Effect of intracerebroventricular alpha-MSH on food intake, adiposity, c-Fos induction, and neuropeptide expression. Am J Physiol Regul Integr Comp Physiol 279:R695-703.

Menzaghi F, Heinrichs SC, Pich EM, Tilders FJ, Koob GF (1993) Functional impairment of hypothalamic corticotropin-releasing factor neurons with immunotargeted toxins enhances food intake induced by neuropeptide $Y$. Brain Res 618:76-82.

Menzaghi F, Howard RL, Heinrichs SC, Vale W, Rivier J, Koob GF (1994) Characterization of a novel and potent corticotropin-releasing factor antagonist in rats. J Pharmacol Exp Ther 269:564-572.

Mihaly E, Fekete C, Lechan RM, Liposits Z (2002) Corticotropin-releasing hormone-synthesizing neurons of the human hypothalamus receive neuropeptide Y-immunoreactive innervation from neurons residing primarily outside the infundibular nucleus. J Comp Neurol 446:235-243.

Murphy B, Nunes CN, Ronan JJ, Hanaway M, Fairhurst AM, Mellin TN (2000) Centrally administered MTII affects feeding, drinking, temperature, and activity in the Sprague-Dawley rat. J Appl Physiol 89:273-282.

Ollmann MM, Wilson BD, Yang YK, Kerns JA, Chen Y, Gantz I, Barsh GS (1997) Antagonism of central melanocortin receptors in vitro and in vivo by agouti-related protein. Science [Erratum (1998) 281:1615] 278:135-138
Poggioli R, Vergoni AV, Bertolini A (1986) ACTH-(1-24) and alpha-MSH antagonize feeding behavior stimulated by kappa opiate agonists. Peptides 7:843-848.

Richard D, Lin Q, Timofeeva E (2002) The corticotropin-releasing factor family of peptides and CRF receptors: their roles in the regulation of energy balance. Eur J Pharmacol 440:189-197.

Rivest S, Deshaies Y, Richard D (1989) Effects of corticotropin-releasing factor on energy balance in rats are sex dependent. Am J Physiol 257:R1417-R1422.

Rossi M, Kim MS, Morgan DG, Small CJ, Edwards CM, Sunter D, Abusnana S, Goldstone AP, Russell SH, Stanley SA, Smith DM, Yagaloff K, Ghatei MA, Bloom SR (1998) A C-terminal fragment of Agouti-related protein increases feeding and antagonizes the effect of alpha-melanocyte stimulating hormone in vivo. Endocrinology 139:4428-4431.

Sarkar S, Legradi G, Lechan RM (2002) Intracerebroventricular administration of alpha-melanocyte stimulating hormone increases phosphorylation of CREB in TRH- and CRH-producing neurons of the hypothalamic paraventricular nucleus. Brain Res 945:50-59.

Steckler T, Holsboer F (1999) Corticotropin-releasing hormone receptor subtypes and emotion. Biol Psychiatry 46:1480-1508.

Suemaru S, Hashimoto K, Hattori T, Inoue H, Kageyama J, Ota Z (1986) Starvation-induced changes in rat brain corticotropin-releasing factor (CRF) and pituitary-adrenocortical response. Life Sci 39:1161-1166.

Swanson LW, Kuypers HG (1980) The paraventricular nucleus of the hypothalamus: cytoarchitectonic subdivisions and organization of projections to the pituitary, dorsal vagal complex, and spinal cord as demonstrated by retrograde fluorescence double-labeling methods. J Comp Neurol 194:555-570.

Swanson LW, Sawchenko PE, Lind RW (1986) Regulation of multiple peptides in CRF parvocellular neurosecretory neurons: implications for the stress response. Prog Brain Res 68:169-190.

Thiele TE, van Dijk G, Yagaloff KA, Fisher SL, Schwartz M, Burn P, Seeley RJ (1998) Central infusion of melanocortin agonist MTII in rats: assessment of c-Fos expression and taste aversion. Am J Physiol 274:R248-254.

Vale W, Spiess J, River C, River J (1981) Characterization of a 41-residue ovine hypothalamic peptide that stimulates secrection of corticotropin and beta-endorphin. Science 213:1394-1397.

Viau V, Sawchenko PE (2002) Hypophysiotropic neurons of the paraventricular nucleus respond in spatially, temporally, and phenotypically differentiated manners to acute vs repeated restraint stress. J Comp Neurol 445:293-307.

Vink T, Hinney A, van Elburg AA, van Goozen SH, Sandkuijl LA, Sinke RJ, Herpertz-Dahlmann BM, Hebebrand J, Remschmidt H, van Engeland H, Adan RA (2001) Association between an agouti-related protein gene polymorphism and anorexia nervosa. Mol Psychiatry 6:325-328.

Von Frijtag JC, Croiset G, Gispen WH, Adan RA, Wiegant VM (1998) The role of central melanocortin receptors in the activation of the hypothalamus-pituitary-adrenal-axis and the induction of excessive grooming. Br J Pharmacol 123:1503-1508.

Watson SJ, Akil H, Richard III CW, Barchas JD (1978) Evidence for two separate opiate peptide neuronal systems. Nature 275:226-228.

Wilson BD, Bagnol D, Kaelin CB, Ollmann MM, Gantz I, Watson SJ, Barsh GS (1999) Physiological and anatomical circuitry between Agoutirelated protein and leptin signaling. Endocrinology 140:2387-2397.

Wirth MM, Giraudo SQ (2001) Effect of Agouti-related protein delivered to the dorsomedial nucleus of the hypothalamus on intake of a preferred versus a non-preferred diet. Brain Res 897:169-174.

Wirth MM, Olszewski PK, Yu C, Levine AS, Giraudo SQ (2001) Paraventricular hypothalamic alpha-melanocyte-stimulating hormone and MTII reduce feeding without causing aversive effects. Peptides 22:129-134.

Yaswen L, Diehl N, Brennan MB, Hochgeschwender U (1999) Obesity in the mouse model of pro-opiomelanocortin deficiency responds to peripheral melanocortin. Nat Med 5:1066-1070. 